\title{
Serum ferritin levels is associated with acute myocardial infarction: a meta-analysis
}

1. Department of Immunology, Nanjing Medical University, Nanjing, 211166, China 2. College of Experience Industry, Anhui Polytechnic University, Wuhu, Anhui 241000, China 3. Children's Hospital of Nanjing Medical University, Nanjing, 210008, China

http://dx.doi.org/10.1590/1806-9282.66.2.227

\section{SUMMARY}

BACKGROUND: An association between increased serum ferritin levels and acute myocardial infarction (AMI) remains controversial. The purpose of this meta-analysis is to confirm the association between increased serum ferritin levels and AMI.

METHODS: We searched PubMed and China National Knowledge Infrastructure (CNKI) for relevant articles that assessed the association between serum ferritin and acute myocardial infarction using terms that included serum ferritin and acute myocardial infarction up to February 13, 2019. Results: A total of 11 studies were identified for analysis. All pooled analysis was based on a random-effects models. The variance was exhibited using a forest plot, and the heterogeneity among studies was examined using the 12 index, the publication bias was evaluated using a funnel plot. The pooled standard mean difference of ferritin levels between AMI and controls was 0.78 (95\% Cl,0.68-0.88).

CONCLUSION: The results of this meta-analysis demonstrate that serum ferritin in acute myocardial infarction patients is higher than that of healthy controls.

KEYWORDS: Myocardial infarction. Ferritins. Meta-analysis.

\section{INTRODUCTION}

Acute myocardial infarction(AMI), a severely wretched status of heart attack, with the classic symptoms of sudden, severe, and persistent pain in the back of the chest (accompanied by pain radiating to the shoulder and sometimes the arm). AMI is currently a cause of mortality and morbidity with high economic costs worldwide'. The damage or death of cardiomyocytes is irreversible. Therefore, we must take medical measures to interfere with its progression. Its wide range of risk factors includes smoking, hypertension, obesity, and dyslipidemia, which have been established as useful predictors for acute myocardial infarction ${ }^{2}$. In addition to these classical risk factors, obesity, fatigue, insufficient sleep, are also risk factors for $\mathrm{AMI}^{3}$. Some studies demonstrate that serum ferritin could be an independent factor in

DATE OF SUBMISSION: 05-Jul-2019

DATE OF ACCEPTANCE: 28-Jul-2019

CORRESPONDING AUTHORS: Changwei Liu

No.72 Guangzhou Road,Nanjing,210008 China. Email:liuchangwei07@163.com;

Lianping $\mathrm{He}$

No.8 Beijing Mid-Road,Wuhu ,241000 China. Email:Lianping He@126.com. 
predicting the risk of AMI. Serum ferritin is a kind of intracellular protein, which regulates the homeostasis of serum iron. Serum iron is essential for oxygen metabolism, especially in the chain that generates adenosine triphosphate through oxidative respiration in the mitochondria ${ }^{4}$. There was been no positive association between serum iron and the risk of cardiovascular diseases in recent studies ${ }^{5,6}$. The objective of this paper was to perform a meta-analysis on the association between serum ferritin and acute myocardial infarction.

\section{METHODS}

\section{Search strategy and data sources}

We searched PubMed and the China National Knowledge Infrastructure (CNKI) for relevant articles that assessed the association between serum ferritin and acute myocardial infarction up to February 13, 2019, using the following medical subject heading (MeSH) terms: "ferritin", and "acute myocardial infarction". In addition, we reviewed the reference lists of the original articles retrieved. There were no language restrictions in the search strategy. Two independent reviewers examined the abstracts of relevant articles and reviewed the full texts in detail. This meta-analysis was performed according to the PRISMA statement, which evaluated the methodological quality?

\section{Study selection}

The following were the inclusion criteria for eligible studies: (1) studies in humans; (2) observational studies, including case-control, cohort studies, and cross-sectional studies; (3) studies conducted to assess the association between ferritin and acute myocardial infarction. The exclusion criteria were: (1) study in animal models or animal experiments; (2) reviews or editorials; (3) case reports or case series; (4) study subjects without acute myocardial infarction.

\section{Data extraction and Statistical analyses}

In Table 1, we present the general characteristics, including the family name of the first author, year of publication, country, study design, source of the paper, the number of participants, and serum ferritin levels.

All statistical analyses were performed using the standardized mean difference (SMD) methodology in MetaXL. The SMD is the pooled difference between AMI groups and control groups on mean values across a group of studies using a different scale of measurement for the outcome. 95\% confidence intervals (CI) were used to measure the precision of the summary estimates. The random-effects model was used to calculate pooled SMD in the presence of heterogeneity. The variance was exhibited using a forest plot. The overall heterogeneity among studies was examined using the $\mathrm{I}^{2}$ index. The publication bias was evaluated using the funnel plot. If the value of $\mathrm{I}^{2}$ was greater than $50 \%$, and the value of $p$ was less than 0.05 , the meta-analysis was considered heterogeneous.

\section{RESULTS}

A total of 236 papers were retrieved from PubMed and the CNKI. A total of 199 results were eliminated

TABLE1. BASIC CHARACTERISTICS OF THE ARTICLES INCLUDED

\begin{tabular}{|c|c|c|c|c|c|c|c|}
\hline \multirow[t]{2}{*}{ Author } & \multirow[t]{2}{*}{ Year } & \multirow[t]{2}{*}{ country } & \multirow[t]{2}{*}{ Study design } & \multirow[t]{2}{*}{ Size } & \multicolumn{3}{|c|}{ Experiment/Control } \\
\hline & & & & & $\mathrm{N}$ & Mean (ug/l) & $\mathrm{SD}(\mathrm{ug} / \mathrm{l})$ \\
\hline Ramesh et al.8 & 2018 & & & 102 & $51 / 51$ & $264.2 / 225.51$ & $40.6 / 45.35$ \\
\hline Yiping9 & 2014 & China & Case-control & 222 & $112 / 110$ & $237.5 / 171.5(\mathrm{~g} / \mathrm{l})$ & $48.4 / 48.4(\mathrm{~g} / \mathrm{l})$ \\
\hline Shipra et al. ${ }^{10}$ & 2014 & India & Case-control & 100 & $50 / 50$ & $\begin{array}{l}\text { 268.43/110.96 (ng/ } \\
\mathrm{ml})\end{array}$ & $30.17 / 56.59(\mathrm{ng} / \mathrm{ml})$ \\
\hline Lqbal et al.. ${ }^{11}$ & 2013 & Pakistan & Case-control & 408 & $203 / 205$ & 158.7/87.1 (ng/ml) & 136.7/74.7 (ng/ml) \\
\hline Wadhwa et al. ${ }^{12}$ & 2013 & India & Case-control & 80 & $40 / 40$ & $279.33 / 245.15(\mathrm{mg} / \mathrm{l})$ & $46.69 / 56.94(\mathrm{mg})$ \\
\hline Holay et al. ${ }^{13}$ & 2012 & India & Case-control & 150 & $75 / 75$ & $324.4 / 155.65$ & $256.8 / 79.76$ \\
\hline Wenxing et al. ${ }^{14}$ & 2005 & China & Case-control & 42 & $22 / 20$ & $333.59 / 166.1$ & $324.6 / 167.1$ \\
\hline Silvia et al. ${ }^{15}$ & 2003 & India & Case-control & 145 & $100 / 45$ & $257.35 / 155.42$ & $76.34 / 76.1$ \\
\hline Claeys et al. ${ }^{16}$ & 2002 & Switzerland & Case-control & 266 & $177 / 89$ & $176 / 131$ & $155 / 106$ \\
\hline Klipstein-Grobusch et al. ${ }^{\mathbf{1 7}}$ & 1999 & Netherlands & Case-control & 172 & $60 / 112$ & $183 / 144$ & $168 / 142$ \\
\hline Moroz et al. ${ }^{18}$ & 1997 & Israel & Case-control & 26 & $20 / 6$ & $113.5 / 110(\mathrm{ng} / \mathrm{ml})$ & $58 / 58(\mathrm{ng} / \mathrm{ml})$ \\
\hline
\end{tabular}


after reading the abstracts. From the remaining papers, six reviews and two animal models were excluded, and 18 references failed to meet the criteria due to lack of data on standard deviation. Finally, 11 articles were included in the study (Figure 1). Four studies were conducted in India, one in China, one in Pakistan, one in Switzerland, one in the Netherlands, and one in Israel.

A total of 1469 participants were analyzed. In
Figure 1, the pooled standard mean difference of ferritin levels between $\mathrm{AMI}$ and controls was $0.78(95 \% \mathrm{CI}$, 0.68-0.88), $\mathrm{p}=0.00, \mathrm{I}^{2}=92 \%$. In Figure 2 and Figure 3, we present the funnel plot for serum ferritin and acute myocardial infarction. Each spot indicates one study with standard error representing the weight of the study and its odds risk. The dashed lines indicate 95\% confidence interval lines, which reflect the symmetry of the pooled estimates.

FIGURE 1. FOREST PLOT FOR THE POOLED DIFFERENCE OF FERRITIN LEVELS

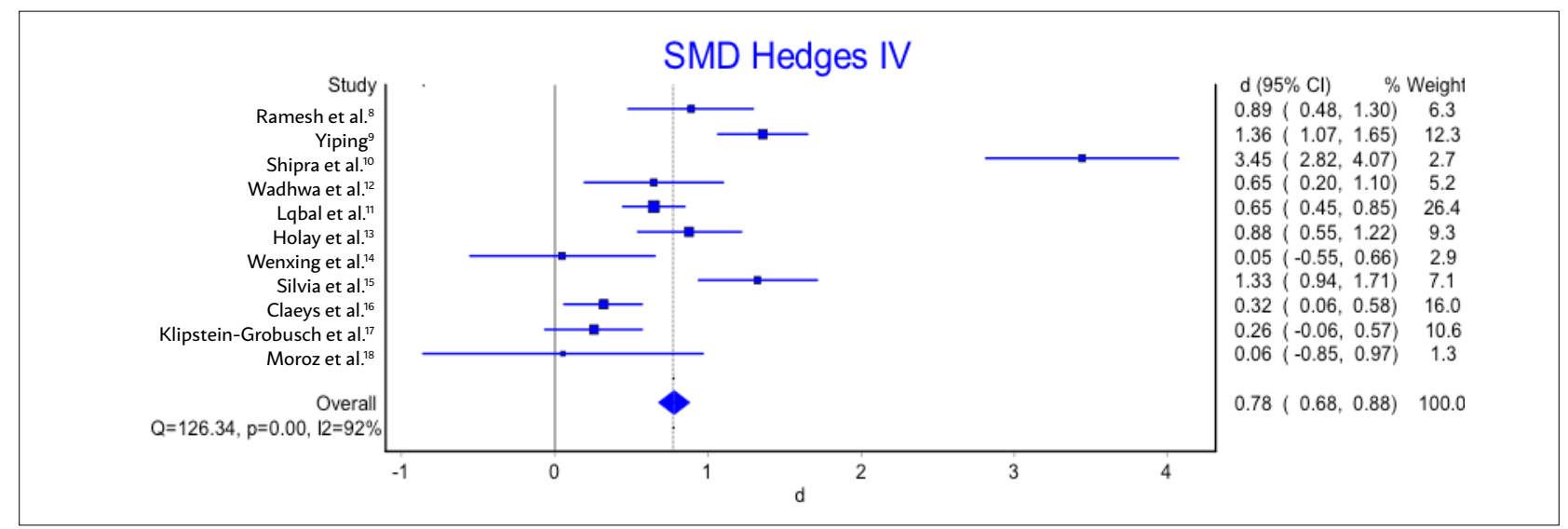

FIGURE 2. PUBLICATION BIAS EVALUATION FOR STUDIES INCLUDED

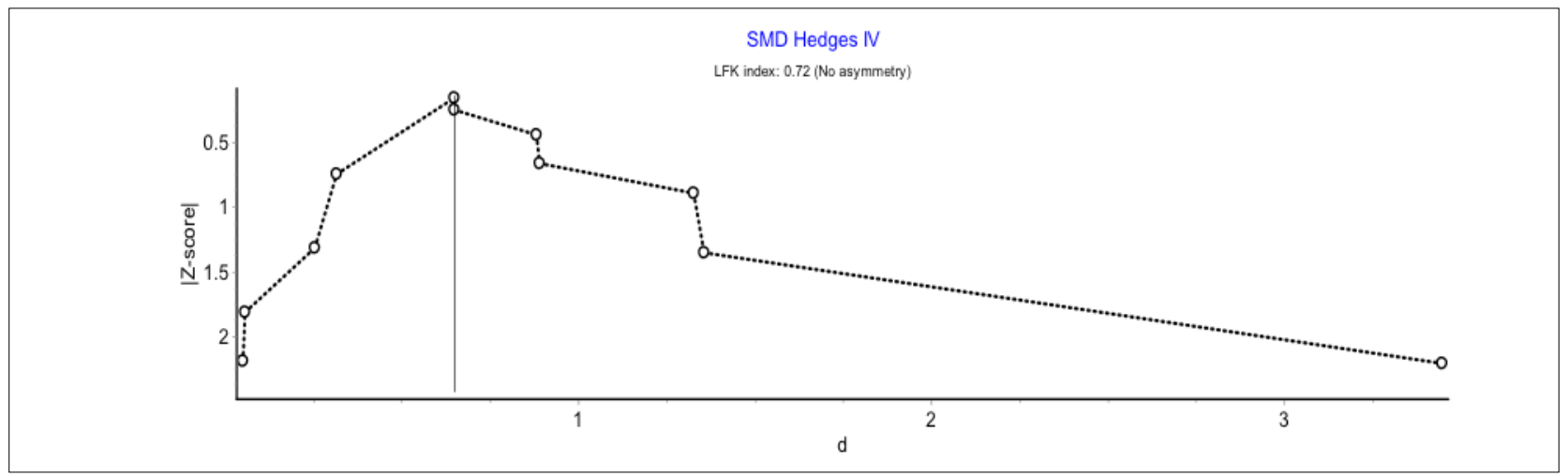

FIGURE 3. FUNNEL PLOT FOR FERRITIN AND ACUTE MYOCARDIAL INFARCTION

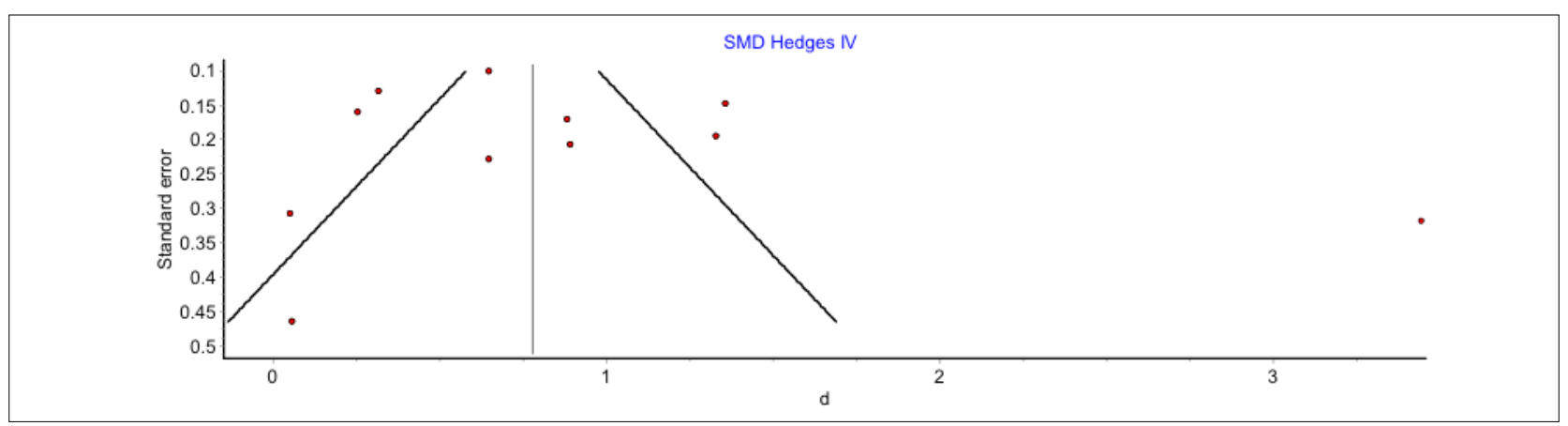




\section{DISCUSSION}

The possibility that high serum ferritin has a role in AMI was first postulated in $1985 .{ }^{19}$ Later, few studies supported the association of high ferritin and acute myocardial infarction, including: (1) Elevated ferritin concentration as a marker of high levels of stored iron, which is a strong risk factor related to acute myocardial infarction. Men with high serum ferritin, not less than 200ug/compared with lower serum ferritin..$^{20}(2)$ A study reported an association between reduced stored serum iron through blood donation and the risk of myocardial infarction; however, a study did not support it. ${ }^{21,22}$ (3)Increased serum levels of ferritin as an independent predictor of the occurrence of acute myocardial infarction, especially ST-elevation acute myocardial infarction. ${ }^{23}$ Our paper is the first meta-analysis that provides few case-control studies on serum ferritin related to acute myocardial infarction and provides insight into its associated risks. In this paper, there is a significantly positive association between serum ferritin and acute myocardial infarction. There is a distinction of serum ferritin in the body between the premenstrual and menstrual stage for the same female participant. In general, the levels of serum ferritin are higher in men than women. The method used to measure the phase of acute myocardial infarction and the corresponding therapeutic measures were different; the followed levels of serum ferritin were not standardized. From all studies included, except for the study by Claeys et al. ${ }^{16}$, the level of LDL-cholesterol in controls was greater than in the cases in the studies by Yiping ${ }^{9}$ and lqbal et al. ${ }^{11}$, respectively, the others were the opposite. In the study by Salonen et al. ${ }^{21}$, the increased serum ferritin accelerated the oxidative metabolism of LDL-cholesterol and induced the process of atherosclerosis, indirectly. ${ }^{24}$ Therefore, the levels of LDL-cholesterol found in all participants of the studies included were a potential factor, which played a role in increased heterogeneity. In the stage of health examination, high levels of serum ferritin, combined with other physical symptoms, could be an indicator of the risk of acute myocardial infarction.

\section{Limitation}

Subjects in our study are moderate; therefore, the limitation is inevitable. There are no follow-up values of serum ferritin from the participants in case groups to compare with the values in the phase of AMI. The sources of heterogeneity remain residual, even though the sensitivity analysis was conducted; thus, the heterogeneity was inevitable in the paper. Nine studies of the eleven included are from Asia; therefore, more studies are needed from other countries in Europe, America, and Africa. Therefore, further studies about the association of serum ferritin and acute myocardial infarction are required.

\section{CONCLUSION}

In sum, the results of this meta-analysis demonstrate that serum ferritin in acute myocardial infarction patients is higher than that of healthy controls.

\section{Author contributions}

SW and LPH designed and organized the research. LPH supervised the study. LY and CWL acquired, analyzed, and interpreted data. LPH performed statistical analysis. SW and LY wrote the manuscript. CWL revised the review. All authors contributed toward data analysis, drafting and critically revising the paper, gave final approval to the version to be published, and agree to be accountable for all aspects of the work.

\section{Disclosure}

The authors report no conflicts of interest in this work.

\section{RESUMO}

Antecedentes: a correlação entre o aumento do nível de proteínas de ferro no soro e o infarto agudo do miocárdio (AMI) continua controversa. O objetivo desta análise é confirmar a relação entre o aumento dos níveis de proteínas de ferro no soro y o AMI. Metodologia: busca de artigos sobre Pubmed e a infraestrutura nacional de conhecimentos da China (cnki) para avaliar a relação entre a proteína de ferro no soro e o infarto agudo do miocárdio, incluída a proteína de ferro no soro e o infarto agudo de miocárdio, até 13 de fevereiro de 2019. Resultado: foram identificados 11 estudos para sua analise e todas as análises resumidas tiveram base em modelos de efeitos aleatórios. Foram utilizados mapas florestais para mostrar as margens, foi utilizado o índice 12 para examinar a heterogeneidade dos estudos e foram utilizados mapas de funil para avaliar os desvios publicados.

A diferença entre a norma de fusão dos níveis de proteína de ferro do Grupo ami e o Grupo de controle é de 0,78 (intervalo de confiança de $95 \%$ 0,68-0,88). Conclusão: nos resultados das análises da meta indicam que os pacientes com infarto agudo do miocárdio têm proteínas de ferro superiores às do Grupo de controle de saúde.

PALAVRAS CHAVE: Infarto do miocárdio. Ferritinas. Metanálise. 


\section{REFERENCES}

1. Collinson P, Lindahl B. Type 2 myocardial infarction: the chimaera of cardiology? Heart. 2015;101(21):1697-703.

2. Gehani AA, Al-Hinai AT, Zubaid M, Almahmeed W, Hasani MR, Yusufali $\mathrm{AH}$, et al; INTERHEART Investigators in Middle East. Association of risk factors with acute myocardial infarction in Middle Eastern countries: the INTERHEART Middle East study. Eur J Prev Cardiol. 2014;21(4):400-10.

3. Du H, Dong CY, Lin QY. Risk factors of acute myocardial infarction in middle-aged and adolescent people (< 45 years) in Yantai. BMC Cardiovasc Disord. 2015;15:106.

4. Vardanyan Z, Trchounian A. Fe(III) and Fe(II) ions different effects on Enterococcus hirae cell growth and membrane-associated ATPase activity. Biochem Biophys Res Commun. 2012;417(1):541-5.

5. Oliveira Otto MC, Alonso A, Lee DH, Delclos GL, Bertoni AG, jiang R, et al. Dietary intakes of zinc and heme iron from red meat, but not from other sources, are associated with greater risk of metabolic syndrome and cardiovascular disease. J Nutr. 2012;142(3):526-33.

6. Muñoz-Bravo C, Gutiérrez-Bedmar M, Gómez-Aracena J, García-Rodríguez A, Navajas JF. Iron: protector or risk factor for cardiovascular disease? Still controversial. Nutrients. 2013;5(7):2384-404.

7. Song F, Sheldon TA, Sutton AJ, Abrams KR, Jones DR. Methods for exploring heterogeneity in meta-analysis. Eval Health Prof. 2001;24(2):126-51.

8. Ramesh G, Sai NVB, Gururaj P, Bhupal R, Patel N. Association of metabolic syndrome and level of hs-CRP, Lp(a), and serum ferritin in young Asian patients ( $\leq 45$ years) with acute myocardial infarction. Interv Med Appl Sci. 2018;10(2):65-9

9. Yiping F. Study on relationship between serum ferritin and acute myocardial infarction. J Shanxi Med Univ. 2014;45:1058-61.

10. Shipra, Gupta BK, Solanki R, Punia H, Agarwal V, Kaur J, et al. Relationship of lipid profile and serum ferritin levels with acute myocardial infarction. Clin Diagn Res. 2014;8(8):CC10-3.

11. Iqbal MP, Mehboobali N, Tareen AK, Yakub M, labal SP, lqbal K, et al. Association of body iron status with the risk of premature acute myocardial infarction in a Pakistani population. PLoS One. 2013;8(6):e67981.

12. Wadhwa A, Avasthi R, Ghambhir JK, Dwivedi S. To study the prevalence and profile of metabolic syndrome, levels of hs-CRP, LP(a) and serum ferritin in young Indian patients ( $<$ or $=45$ years) with acute myocardial infarction. | Assoc Physicians India. 2013;61(6):384-6.

13. Holay MP, Choudhary AA, Suryawanshi SD. Serum ferritin: a novel risk factor in acute myocardial infarction. Indian Heart J. 2012;64(2):173-7.

14. Wenxing F, Xuesheng $L$. Analysis of serum ferritin level in patients with acute myocardial infarction. Shandong Med J. 2005;45:43.

15. Silvia WD, Biswas S, Uthappa S, Shetty P. Ferritin, a potent threat for acute myocardial infarction? J Assoc Physicians India. 2003;51:947-50.

16. Claeys D, Walting M, Julmy F, Wuillemin WA, Meyer BJ. Haemochromatosis mutations and ferritin in myocardial infarction: a case-control study. Eur J Clin Invest. 2002;32(Suppl 1):3-8.

17. Klipstein-Grobusch $\mathrm{K}$, Koster JF, Grobbee DE, Lindemans |, Boeing $\mathrm{H}$, Hofman A, et al. Serum ferritin and risk of myocardial infarction in the elderly: the Rotterdam Study. Am J Clin Nutr. 1999;69(6):1231-6.

18. Moroz C, Bessler H, Katz M, Zahavi I, Salman H, Djaldetti M. Elevated serum ferritin level in acute myocardial infarction. Biomed Pharmacother. 1997;51(3):126-30.

19. Camps C, Alberola V, Llavador |, Moreno |L, Labiós M, García-Conde F). Serum ferritin in acute myocardial infarction. Rev Esp Cardiol. 1985;38(3):177-9.

20. Salonen JT, Nyyssönen K, Korpela H, Tuomilehto J, Seppänen R, Salonen R. High stored iron levels are associated with excess risk of myocardial infarction in eastern Finnish men. Circulation. 1992;86(3):803-11.

21. Salonen IT, Tuomainen TP, Salonen R, Lakka TA, Nyyssönen K. Donation of blood is associated with reduced risk of myocardial infarction. The Kuopio Ischaemic Heart Disease Risk Factor Study. Am J Epidemiol. 1998;148(5):445-51.

22. Ascherio A, Rimm EB, Giovannucci E, Willett WC, Stampfer MI. Blood donations and risk of coronary heart disease in men. Circulation. 2001;103(1):52-7.

23. Moradi M, Fariba F, Mohasseli AS. Relation between the serum ferritin level and the risk for acute myocardial infarction. J Res Health Sci. 2015;15(3):147-51.

24. Ikeda Y, Suehiro T, Yamanaka S, Kumon Y, Takata H, Inada S, et al. Association between serum ferritin and circulating oxidized low-density lipoprotein levels in patients with type 2 diabetes. Endocr J. 2006;53(5):665-70. 